\title{
Senile sebaceous nevus degenerating to a pseudo glandular basal cell carcinoma
}

\begin{abstract}
Jadassohn nevus is a congenital hamartoma that is characterized by natural evolution in three stages, with a risk of malignancies occurring in the last phase. This benign adnexal tumor often affects the face and scalp. Dermoscopy can provide a major help for detecting transforming tumors. We report the case of a senile sebaceous Nevus which has been diagnosed after the occurrence of Basal cell carcinoma in a 60 years old man. The originality of this observation remains in the rarity of the pseudo glandular basal cell carcinoma that, in the best of our knowledge, has never been reported in underlying nevus sebaceous.
\end{abstract}

Keywords: sebaceous nevus, dermoscopy, basal cell carcinoma
Volume II Issue 2 - 2020

\author{
Khadija Elboukhari,Asmae Rasso, Sara \\ Elloudi, Hanane Baybay, Zakia Douhi, Fatima \\ Zahra Mernissi \\ Department of Dermatology, University Hospital of Fez, \\ Morocco
}

Correspondence: Khadija Elboukhari, Department of
Dermatology, University Hospital of Fez, Morocco,
Tel +2I 262 II I 9073, Email elbokharikhadija89@gmail.com

Received: February 26, 2020 | Published: March 18, 2020

\section{Introduction}

Sebaceous nevus or Jadassohn nevus is a benign adnexal tumor that often occurs in the face and scalp. ${ }^{1}$ This congenital hamartoma is characterized by a risk of transforming especially in the adolescent stage. Dermoscopy is a non-invasive imaging technique that provides a major help for detecting transforming tumors by giving highly specific features. ${ }^{2}$ Prophylactic surgery has a large place in the management of this entity.

\section{Case observation}

A 60 years old man consulted in our training for a lesion of the forehead evolving for 2 years, occurring on a congenital lesion, this patient had already benefited from his referring doctor, a skin biopsy which revealed a basal cell carcinoma. When examining our patient we noted an infiltrated plaque, containing in its upper part an ulcerated pigmented nodule, in its middle part a scar of biopsy of normal appearance and in its lower part a yellowish plaque, slightly infiltrated, ulcerated by location (Figure 1). When we put our Dermoscopy, we found in the upper area of the lesion, blue-gray ovoid nests with large ulceration and, in the surrounding area, we noted bright yellow spots (Figure 2). We evocated then a basal cell carcinoma or a trichoblastoma in an underlying sebaceous nevus. Our patient has had a total lesion excision total with $0,5 \mathrm{~mm}$ marges. histopathological examination of the total lesion showed a basaloid cell proliferation with pseudo glandular disposition, adjacent to a hypertrophic sebaceous gland (Figure 3).

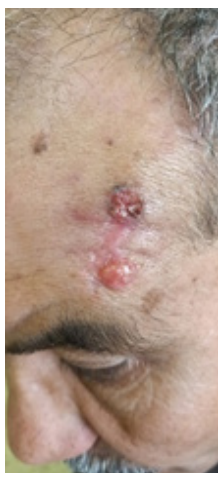

Figure I Pigmented ulcerated nodule separated from a yellowish translucent plaque by a biopsy scar, located in the left frontal area.

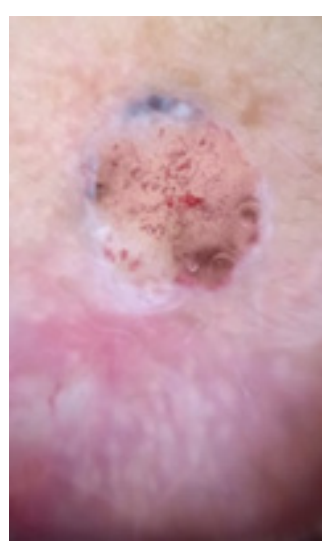

Figure 2 Ovoid nets and large ulceration seen by dermoscopy on the pigmented nodule, with yellow dots in the translucent part of the lesion corresponding to the congenital hamartoma.

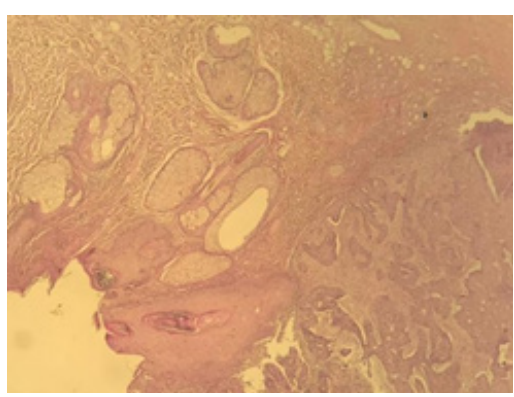

Figure 3 GxI00 HES stain: basaloid cell proliferation with pseudoglandular disposition, adjacent to a hypertrophic sebaceous gland.

\section{Discussion}

Nevus sebaceous is a complex hamartoma that occurs since birth, and involve the epidermis and dermis, with a triphasic evolution: alopecic patch with underdeveloped adnexal structures. In puberty, the second phase shows a proliferative and veracious plaque. While the third phase is characterized by the occurrence of benign or more rarely invasive tumors in the preexistent plaque. ${ }^{3}$ Dermoscopy finds an important place in the characterization of these stages of evolution, and especially in the detection of transformation. $10-20 \%$ of sebaceous nevus is transformed into benign or malignant tumors that 
may be epidermal, adnexal or parenchymatous. ${ }^{4,5}$ This transformation occurs generally in adult life as solitary or several nodules within the confines of the naevus. ${ }^{3}$ The most common neoplasm occurring in nevus sebaceous is trichoblastoma, ${ }^{3,6,7}$ followed by basal cell carcinoma, ${ }^{3}$ those entities present clinic dermoscopical similarities. In fact, in referring to Zaballos et al. ${ }^{3}$ study Blue-gray ovoid nests, arborizing vessels, and telangiectasis are described in both tumors. ${ }^{3}$ While other studies attach blue-gray nets to only basal cell carcinoma. ${ }^{2}$ This dermoscopic features can also be found in hydrocystoma and hidradenoma that occurs rarely in sebaceous nevus. ${ }^{3}$ Other malignant tumors can occur in this congenital hamartoma, such are Squamous cell carcinoma ${ }^{8}$ and sebaceous carcinoma. ${ }^{9}$

On the other hand, in our case we noted a rare subtype of basal cell carcinoma, which is the pseudo glandular variety. To the best of our knowledge, there are no similar cases reported in the literature.

\section{Conclusion}

Although the main risk of transformation is in adolescent age, a delayed cancerization may occur especially in the elderly, that justify a regular dermoscopic control of this tumor if a prophylactic surgery has not been conducted.

\section{Funding}

None.

\section{Acknowledgments}

None.

\section{Conflicts of interest}

The authors declare there are no conflicts of interest.

\section{References}

1. Pereira LB, Gontijo B, Silva CM. Dermatoses neonatais. An Bras Dermatol. 2001;76:505-537.

2. Enei ML, Paschoal FM, Valdés G, et al. Basal cell carcinoma appearing in a facial nevus sebaceous of Jadasshon: dermoscopic features. An Bras Dermatol. 2012;87(4):640-642.

3. Zaballos P, Serrano P, Flores G, et al. Dermoscopy of tumours arising in naevus sebaceous: a morphological study of 58cases. J Eur Acad Dermatol Venereol. 2015;29(11):2231-2237.

4. Munoz-Perez MA, Garcia-Hernandez MJ, Rios JJ, et al. Sebaceus naevi: a clinicopathologic study. J Eur Acad Dermatol Venereol. 2002;16(4):319324.

5. Rosen H, Schmidt B, Lam HP et al. Management of nevus sebaceous and the risk of Basal cell carcinoma: an 18-year review. Pediatr Dermatol. 2009;26(6):676-681.

6. Gouillon L, Thomas L, Dalle S. Trichoblastoma and superficial basal cell carcinoma arising in naevus sebaceous. Ann Dermatol Venereol. 2017;144(2):154-155.

7. Jaqueti G, Requena L, Sánchez Yus E. Tricoblastoma is the most common neoplasm developed in nevus seba-6. ceous of Jadassohn: a clinicopathologic study of a series of 155 cases. Am J Dermatopathol. 2000;22(2):108-118.

8. Ball EA, Hussain M, Moss AL. Squamous cell carcinoma and basal cell carcinoma arising in a naevus sebaceous of Jadassohn: case report and literature review. Clin Exp Dermatol. 2005;30(3):259-260.

9. Miller CJ, Ioffreda MD, Billingsley EM. Sebaceous carcinoma, basal cell carcinoma, trichoadenoma, trichoblastoma, and syringocystadenoma papilliferum arising within a nevus sebaceus. Dermatol Surg. 2004;30(12 Pt 2):1546-1549. 